AperTO - Archivio Istituzionale Open Access dell'Università di Torino

Squaraines bearing halogenated moieties as anticancer photosensitizers: Synthesis, characterization and biological evaluation

This is a pre print version of the following article:

Original Citation:

Availability:

This version is available http://hdl.handle.net/2318/1575374

since 2016-09-13T18:01:38Z

Published version:

DOI:10.1016/j.ejmech.2016.02.035

Terms of use:

Open Access

Anyone can freely access the full text of works made available as "Open Access". Works made available under a Creative Commons license can be used according to the terms and conditions of said license. Use of all other works requires consent of the right holder (author or publisher) if not exempted from copyright protection by the applicable law. 
This Accepted Author Manuscript (AAM) is copyrighted and published by Elsevier. It is posted here by agreement between Elsevier and the University of Turin. Changes resulting from the publishing process - such as editing, corrections, structural formatting, and other quality control mechanisms - may not be reflected in this version of the text. The definitive version of the text was subsequently published in EUROPEAN JOURNAL OF MEDICINAL CHEMISTRY, 113, 2016, 10.1016/j.ejmech.2016.02.035.

You may download, copy and otherwise use the AAM for non-commercial purposes provided that your license is limited by the following restrictions:

(1) You may use this AAM for non-commercial purposes only under the terms of the CC-BY-NC-ND license.

(2) The integrity of the work and identification of the author, copyright owner, and publisher must be preserved in any copy.

(3) You must attribute this AAM in the following format: Creative Commons BY-NC-ND license (http://creativecommons.org/licenses/by-nc-nd/4.0/deed.en), 10.1016/j.ejmech.2016.02.035

The publisher's version is available at:

http://linkinghub.elsevier.com/retrieve/pii/S0223523416301155

When citing, please refer to the published version.

Link to this full text:

http://hdl.handle.net/None 


\section{Squaraines bearing halogenated moieties as anticancer photosensitizers: synthesis, characterization and biological evaluation}

Loredana Serpe $^{\mathrm{a}}$, Silvano Ellena ${ }^{\mathrm{b}}$, Nadia Barbero ${ }^{\mathrm{b}, *}$, Federica Foglietta $^{\mathrm{a}}$, Federica Prandini ${ }^{\mathrm{a}}$, Maria Pia Gallo $^{\mathrm{c}}$, Renzo Levi ${ }^{\mathrm{c}}$, Claudia Barolo ${ }^{\mathrm{b}}$, Roberto Canaparo ${ }^{\mathrm{a}}$, Sonja Visentin ${ }^{\mathrm{d}}$

${ }^{\text {a } U n i v e r s i t y ~ o f ~ T o r i n o, ~ D e p a r t m e n t ~ o f ~ D r u g ~ S c i e n c e ~ a n d ~ T e c h n o l o g y, ~ V i a ~ P i e t r o ~ G i u r i a ~ 13, ~} 10125$ Torino, Italy.

${ }^{\mathrm{b}}$ University of Torino, Department of Chemistry and NIS Interdepartmental Centre, Via Pietro Giuria 7 , 10125, Torino, Italy. nadia.barbero@unito.it

${ }^{\mathrm{c}}$ University of Torino, Department of Life Sciences and Systems Biology, Via Accademia Albertina 13, 10123 Torino, Italy.

${ }^{\mathrm{d}}$ University of Torino, Department of Molecular Biotechnology and Health Science, via Quarello15, 10135, Torino, Italy.

* corresponding author 


\section{AbSTRACT}

We report the synthesis and characterization of a series of symmetrical indolenine-based squaraine dyes along with the evaluation of their singlet oxygen generation efficiency. The photodynamic activity of these new photosensitizers has been evaluated on a human tumor fibrosarcoma (HT-1080) cell line. The cytotoxicity increased over time and is induced by the photoactivation of bromo (Br-C4) and iodio (I-C4) long carbon chain squaraine dyes and the consequent increase in reactive oxygen species $(\mathrm{ROS})$ production $(\mathrm{p}<0.001)$, which leads to necrosis $6 \mathrm{~h}$ after treatment. Induction of cytochrome c release, DNA damage and up-regulation of GPX1, NQO1 and SOD2 mRNA gene expression after PDT were investigated.

\section{KEYWORDS}

Squaraines; photodynamic therapy; photosensitizers; singlet oxygen; cancer. 


\section{INTRODUCTION}

Photodynamic therapy (PDT) is an emerging non-invasive technique for the treatment of both cancer and non-cancerous conditions [1,2]. It involves the systemic or topic administration of a photosensitizer (PS) that, after its excitation with light at a specific wavelength, is able to produce reactive oxygen species (ROS), causing damage to targeted cancer cells. The most important of these oxygen species is widely believed to be singlet oxygen $\left({ }^{1} \mathrm{O}_{2}\right)$ [3]. In particular, an ideal PS should fulfill specific, clinically relevant requirements: i) sharp, intense absorption in the biological tissues' transparency window $(600-900 \mathrm{~nm})$, ii) good solubility in the biological environment, iii) low dark toxicity but strong photo-cytotoxicity and a high ${ }^{1} \mathrm{O}_{2}$ sensitization quantum yield. Moreover, an ideal PS should possess a high specificity for cancer tissues and be easily and rapidly removed from the body post-treatment $[4,5]$.

Several PS have already been proposed and some of them, belonging to the porphyrin family, are clinically used [6,7]. However, porphyrins show a number of drawbacks, including relatively poor photo-stability, weak absorption above $600 \mathrm{~nm}$, low solubility in water, serious skin photosensitization and specific (sometimes undesired) biodistribution. The search for more effective PS has therefore become a relevant issue and squaraine dyes deserve to be counted among the innovative potential PS classes for photodynamic treatment.

Squaraines are the products of dicondensation reactions between electron-rich substrates and squaric acid. Interest in this old class of organic dyes has been renewed quite recently due to their photophysical and photochemical properties, i.e. a high extinction coefficient with an intense absorption and fluorescence in the red/near-IR region (between 600 and $850 \mathrm{~nm}$ ) [8]. These properties, along with relative easy tuning syntheses, make squaraine dyes very attractive for their use in a large number of fields, such as solar-energy conversion [9], nonlinear optics, biological applications [10] and sensitizers for PDT [11]. Indeed, Ramaiah et al. have stated that appropriately substituted squaraine dyes can act as novel sensitizers in PDT applications [12] and are interesting also for their strong absorption in the tissue transparency window $(600-800 \mathrm{~nm})$. They demonstrated 
that the quantum yield for the photosensitised ${ }^{1} \mathrm{O}_{2}$ generation of phloroglucinol could be increased significantly by halogenating the donor moiety with heavier halogen atoms. Furthermore, squaraines are scarcely cytotoxic in the dark, but after irradition, they promote a strong dosedependent phototoxic effect in different cancer cells lines [13].

In this study, we report the synthesis and characterization of a series of halogenated symmetric squaraines which bear chains of different lengths on their nitrogen atoms (Scheme 1). The photodynamic activity of these new squaraine based photosensitizers has been evaluated on a human fibrosarcoma (HT-1080) cell line by analyzing the effect of photodynamic treatment on cell proliferation, cell death, intracellular ROS generation, cytochrome c release, DNA damage and mRNA gene expression.

\section{RESULTS AND DISCUSSION}

\subsection{Synthesis}

The classic synthesis of symmetrical squarylium dyes entails the one-pot condensation of electronrich aromatic or heterocyclic compounds with squaric acid in a solvent mixture under reflux [14]. Barbero et al. have recently proposed an alternative method which makes use of a microwave synthesizer [15]. The main advantages of this synthetic approach are decreased reaction times (from 6-12 $\mathrm{h}$ to $20-50 \mathrm{~min}$ ) and increased squaraine yield and purity.

This general synthetic procedure starts with the synthesis of the indolenine ring. In this work, the starting 5-substituted 2,3,3-trimethylindolium (2a-b) were readily obtained via the condensation of benzohydrazine substitute 1a-b with 3-methylbutan-2-one in glacial acetic acid, as previously reported $[15,16]$ (see Scheme 2). The subsequent step is the quaternization of the indolenine ring: thanks to the nitrogen quaternization, an increase of the acidity of the methyl group will occur enabling the bridge formation. Quaternarized salts are previously published compounds and their 
characterization agrees with literature values. (3a-C2 [17]), (3b-C2 [18]), (3a-bC4 [19,20]). In the final step, squaric acid is overheated in a closed vessel under MW radiation with a 2-fold excess of the quaternized indolenine in 1-butanol:toluene mixture $(1: 1, \mathrm{v} / \mathrm{v})$. (Scheme 3 , for more details see the Experimental section).

\subsection{Generation of singlet oxygen}

A qualitative and comparative study of the abilities of a series of squaraines to generate singlet oxygen was carried out by trapping ${ }^{1} \mathrm{O}_{2}$ with 1,3-diphenylisobenzofuran (DPBF) [21]. In fact DPBF reacts rapidly with ${ }^{1} \mathrm{O}_{2}$ forming the colorless o-dibenzoylbenzene derivative, resulting from the disappearance of DPBF's characteristic absorption band at $415 \mathrm{~nm}$. Thus, a solution of DPBF $(20 \mu \mathrm{M})$ and squaraine dyes $(5 \mu \mathrm{M})$ in PBS pH 7.4 and DMSO (1\%) was irradiated in a filtered solar box to remove the wavelengths below $515 \mathrm{~nm}$ while DPBF consumption was monitored over time. The decrease in quencher absorption at $415 \mathrm{~nm}$, as a function of the squaraine irradiation time, has been compared to the values obtained from methylene blue (MB), an efficient and well-known singlet oxygen generator, proving that all squaraines possess ${ }^{1} \mathrm{O}_{2}$ generation ability (Figure 1). In particular SQ-NH promoted the complete decay of DPBF absorption within 60 min, while the same result was obtained in 5-10 min for halogenated SQ. The presence of both bromine and iodine may facilitate the singlet to triplet state intersystem crossing that is due to the well-known heavy atom effect [12].

\subsection{In vitro photodynamic activity}

\subsubsection{Effect of squaraine dye-based photodynamic treatment on HT-1080 cell proliferation}


As shown in Figure 2, HT-1080 cells were exposed to varying squaraine dye concentrations (from 0.25 to $10 \mu \mathrm{M}$ ) in order to detect the correct non-cytotoxic concentration with which to perform photodynamic experiments. A dose-dependent increase in cytotoxicity was observed after squaraine dyes incubation. It is clear that the highest squaraine dye concentration $(10 \mu \mathrm{M})$ is already cytotoxic to HT-1080 at 24 hours, and for up to 72 hours, after administration. Lower cytotoxicity was observed over time when cells were exposed to a $2 \mu \mathrm{M}$ squaraine dye concentration, specifically with Br-C2, Br-C4 and I-C4. Exposing HT-1080 cells to squaraine dyes, from 0.25 to $1 \mu \mathrm{M}$ and for up to $72 \mathrm{~h}$, did not affect cell viability. All cells were incubated at the highest non-toxic concentration tested $(1 \mu \mathrm{M})$ of squaraine dyes.

The intracellular uptake of squaraine dyes was also evaluated cytofluorimetrically, as observed in Figure 3. Br-NH and I-NH gave significant cellular uptake up to $6 \mathrm{~h}(\mathrm{p}<0.05)$ after incubation, while SQ-NH uptake remained for up to $24 \mathrm{~h}(\mathrm{p}<0.05)$. However, cellular uptake was significantly increased over time when squaraine dyes were characterized with two (Br-C2 and I-C2) or four (Br$\mathrm{C} 4$ and I-C4) carbon chains. Indeed, Br-C4 and I-C4 squaraine dyes already present significant intracellular uptake at $3 \mathrm{~h}(\mathrm{p}<0.05)$ and for up to $24 \mathrm{~h}(\mathrm{p}<0.001)$ after incubation, as can be seen in their high iMFI ratio.

The photodynamic effects of all the squaraines were observed for up to $72 \mathrm{~h}$ after photodynamic treatment. The control treatments, i.e., exposure to squaraine derivatives or appropriate wavelength light beams alone $\left(\mathrm{LB}, 15 \mathrm{~mW} / \mathrm{cm}^{2}\right.$ for $\left.20 \mathrm{~min}\right)$ did not affect HT-1080 cell proliferation, as seen in Figure 4. Moreover, there was no reduction in cell growth when cells were treated with PDT and SQ-NH, Br-NH or I-C2, whereas a slight reduction in cell growth was observed with I-NH at $72 \mathrm{~h}$ and with Br-C2 at $48(\mathrm{p}<0.01)$ and $72(\mathrm{p}<0.001) \mathrm{h}$ after PDT. It is worth noting that only when cells were preincubated with $\mathrm{Br}-\mathrm{C} 4$ or I-C4 it was possible to significantly decrease HT-1080 cell proliferation at $24 \mathrm{~h}(\mathrm{p}<0.05)$ and up to $72 \mathrm{~h}(\mathrm{p}<0.001)$. Thus, it would appear that squaraine dye photodynamic activity may be influenced by the presence of long carbon chains in the squaraine dye chemical structure. Indeed, this hypothesis also 
correlates with the increased iMFI index over time observed in $\mathrm{Br}-\mathrm{C} 2, \mathrm{I}-\mathrm{C} 4, \mathrm{Br}-\mathrm{C} 4$ and $\mathrm{I}-\mathrm{C} 4$, as compared to the other squaraine dyes (Figure 3).

\subsection{Confocal colocalization of Br-C4 and I-C4 in HT-1080 mitochondria}

It has been suggested that mitochondria are a major subcellular site for photosensitizer localization, and that squaraine dyes localize in mitochondria organelles [22]. We therefore decided to perform a confocal fluorescent analysis of HT-1080 mitochondria, stained with MitoTracker Green, and $\mathrm{Br}-\mathrm{C} 4$ and I-C4 in order to establish the colocalization. Figure 5 shows that $\mathrm{Br}-\mathrm{C} 4$ (panel C) was partially colocalized with the mitochondrial region, while more striking colocalization was shown for I-C4 (panel F) and cellular mitochondria, revealing identical overlap in the transcellular fluorescence localization profiles. These data appear to strongly suggest that BrC4 and I-C4 are held by cellular mitochondria once they penetrate cells.

\subsection{Effects of Br-C4 and I-C4 photodynamic treatment on reactive oxygen species production}

The mechanism of action of most PS has revealed that light irradiation of PS and subsequent energy transfer can lead to a series of photochemical reactions, in the presence of $\mathrm{O}_{2}$, and the generation of various cytotoxic species (e.g. ${ }^{1} \mathrm{O}_{2}$ and $\mathrm{ROS}$ ), which consequently induce cellular damage via apoptosis/necrosis [23]. In the present work, 2',7' dichlorofluorescin diacetate (DCFHDA) has been used as a ROS probe to examine photodynamic treatment induced ROS generation. In fact, highly fluorescent DCF can be evaluated by flow cytometry at an excitation of $488 \mathrm{~nm}$ in the presence of peroxides. Intracellular ROS levels were determined 1, 5, 15, 30, 45 and 60 min after photodynamic treatment with either LB alone $\left(15 \mathrm{~mW} / \mathrm{cm}^{2}\right.$ for $\left.20 \mathrm{~min}\right)$ or in combination with either Br-C4 or I-C4 $(1 \mu \mathrm{M})$. Figure 6 shows that combined LB and Br-C4/I-C4 treatment induced a significant increase in ROS production 1 min after treatment $(\mathrm{p}<0.001)$, and that this progressively decreased over time up to $15 \min (\mathrm{p}<0.05)$. The iMFI ratio was highest when cells were treated 
with Br-C4 and exposed to PDT; a 30-fold increase was observed 1 min after the treatment $(32.00 \pm$ 4.24). However, the photoexcitation of I-C4 only gave a 15 -fold ROS increase (15.32 \pm 5.20$)$. In vitro ROS production suggested that the presence of both bromine and iodine may facilitate the singlet to triplet state intersystem crossing that is due to the well-known heavy atom effect. Our results are furthermore in line with Soumya's work, where an increase in ROS production was obtained when Ehrlich's Ascites Carcinoma (EAC) cells were treated with a symmetrical diiodinated benzothiazolium squaraine (SQDI) and then photo-treated [24].

\subsection{Effects of photodynamic treatment with Br-C4 and I-C4 on HT-1080 cell death, cytochrome c} release and DNA damage

The photoactivation of a PS is correlated to events that culminate with apoptosis, leading to cell destruction. In particular, it has been reported that the photoactivation of a PS, such as a squaraine dye, triggers the apoptotic cell death pathway [25]. Cell proliferation data obtained after squaraine dye photoactivation prompted us to focus our attention on $\mathrm{Br}-\mathrm{C} 4$ and I-C4 squaraine dyes, which showed increased activity in cell proliferation reduction (Figure 4). As observed in Figure $7 \mathrm{~A}, 80 \%$ of the cells that had previously been exposed to $\mathrm{Br}-\mathrm{C} 4(\mathrm{p}<0.001,81.90 \pm 0.14)$ or I-C4 $(p<0.001,83.00 \pm 6.09)$ were found to be necrotic, by being positive to Annexin V-Alexa Fluor ${ }^{\circledR} 488$ and Propidium Iodide (PI), 6 h after combined treatment with PDT $\left(15 \mathrm{~mW} / \mathrm{cm}^{2}\right.$ for 20 min), while no change in necrotic and apoptotic events was observed when cells were only exposed to squaraine dyes or LB alone. Our results are in line with Rapozzi's work, where squaraine photoactivation after HeLa cell line incubation induced an increase in necrotic events [13]. It was decided to evaluate the release of cytochrome $\mathrm{c}$ in cytosolic extracts of HT-1080 cells that had been treated with $\mathrm{Br}-\mathrm{C} 4$ or I-C4 for $24 \mathrm{~h}$ and then exposed to PDT. This is because cytochrome c mitochondrial release occurs almost immediately after PDT and is specific to oxidative stress [26]. Figure 7B shows a statistically significant and rapid increase, as compared to untreated cells, in the 
release of mitochondrial cytochrome $\mathrm{c}$ into cytosol $0.5 \mathrm{~h}$ after PDT with both squaraine dyes $(\mathrm{p}<$ 0.001). This is followed by a drastic reduction in release $3 \mathrm{~h}$ after the treatment. Despite our data being statistically significant, we did not find constant or increased cytosolic cytochrome c release over time after photoexposure. These differing cytochrome c release kinetics point to necrosis being the principle cell death pathway induced by the photoactivation of squaraine dyes.

Although the exact mechanism of damage to the various cellular targets in PDT has been a matter of debate in recent years, it has been reported that both Type I and Type II reactions involved in PDT can damage cellular constituents (lipids, proteins, DNA) and eventually cause cell death. Moreover, it is likely that $\mathrm{Br}-\mathrm{C} 4$ and I-C4 squaraine dye photodynamic activity affects DNA and so we decided to evaluate the treatment's effect on DNA damage. As observed in Figure 7C, PDT with either squaraine dye $(\mathrm{p}<0.05)$ caused significant DNA damage. Our results are in line with Ramaiah's work, where massive damage to DNA was also observed after the photoirradiation of Chinese hamster ovary (ASS2) cells that had previously been incubated with halogenated squaraine dyes [25].

\subsection{Effect of Br-C4 or I-C4 photodynamic treatment on gene expression}

In order to profile the changes in gene expression patterns in $\mathrm{Br}-\mathrm{C} 4$ or I-C4 photodynamic induced necrosis and ROS production, total RNA was harvested from HT-1080 0.5, 3 and $24 \mathrm{~h}$ after PDT with squaraine dyes. Analyzed genes were grouped by function; either as genes involved in the induction of apoptosis or the oxidative damage pathway, as shown in Figure 8A and B.

In agreement with our previous data, both $\mathrm{Br}-\mathrm{C} 4$ and I-C4 photodynamic activities induced an increase in necrosis (Figure 7A). Indeed, there was no significant post-PDT up-regulation in the mRNA expression of pro apoptotic $(B A X)$ and Apoptotic Peptidase Activating Factor 1 (APAF1), which are involved in programmed cell death. Furthermore, the down-regulation of anti-apoptotic BCL-2 mRNA expression was observed over all times considered, although it was not statistically 
significant (Figure 8A). We observed a significant up-regulation in tumor suppressor TP-53 mRNA expression $3 \mathrm{~h}$ after PDT activity with $\mathrm{Br}-\mathrm{C} 4$, but not after I-C4 PDT activity.

We investigated the genes involved in ROS production (Figure 8B), and observed a significant increase in the expression of GPX1 mRNA, one of the most important antioxidant enzymes in the detoxification of hydrogen peroxide, $0.5 \mathrm{~h}$ after $\mathrm{Br}-\mathrm{C} 4(\mathrm{p}<0.001)$ and I-C4 $(\mathrm{p}<$ 0.001) PDT activity and followed its progressive decrease over time. It is important to underline the large difference in the expression of GPX1 and that of the other genes analyzed; more than 30- and 50-fold after PDT with Br-C4 (34.58 \pm 5.32$)$ and I-C4 (54.63 \pm 5.05$)$, respectively. Figure $8 \mathrm{~B}$ shows that NQO1, another gene involved in detoxification systems, was significantly up-regulated $0.5 \mathrm{~h}$ after PDT with both Br-C4 $(\mathrm{p}<0.05,3.39 \pm 0.50)$ and $\mathrm{I}-\mathrm{C} 4(\mathrm{p}<0.01,5.56 \pm 0.78)$. This again was followed by a progressive decrease over time, up to $24 \mathrm{~h}$ after treatment. We observed a significant up-regulation of superoxide dismutase type 2 (SOD2) mRNA gene expression $0.5 \mathrm{~h}$ after PDT treatment with I-C4 ( $\mathrm{p}<0.01,5.21 \pm 0.49)$, but not after Br-C4 PDT. If we consider the gene expression pathways that have been studied so far, it is possible to hypothesize that the photoactivation of $\mathrm{Br}-\mathrm{C} 4$ and I-C4 squaraine dyes induces the consistent up-regulation of genes involved in the oxidative pathway, such as $G P X-1, N O Q 1$ and $S O D 2$, which itself reflects the massive recruitment (induction) of ROS (Figure 6). 


\section{CONCLUSiON}

In conclusion, we have described the synthesis of highly fluorescent near-IR halogenated squaraine dyes and their in vitro photoactivation in a human fibrosarcoma (HT-1080) tumor cell line. It has been observed that the presence of bromine $(\mathrm{Br}-\mathrm{C} 2, \mathrm{Br}-\mathrm{C} 4)$ or iodine (I-C2, I-C4) facilitates the singlet to triplet state intersystem crossing that is due to the well-known heavy atom effect. Different in vitro photodynamic activity was observed for each squaraine dye. Specifically, only photodynamic treatment with $\mathrm{Br}-\mathrm{C} 4$ or I-C4 was able to cause significant reductions in cancer cell growth. These data also confirm an impressive increase in iMFI ratio. From a SAR (structureactivity relationship) point of view, this increase may be caused by the presence of a four carbon chain that improved cellular uptake probably due to the increase of lipophilicity. It is well known that lipophilicity influences the ADMET characteristics of drugs contributing to their solubility and permeability through biological membranes. So we can conclude that not only the presence of heavy atoms on the squaraine structures will influence the pharmacological activity, but also their hydrophilic-lipophilic balance.

Moreover, the effective intracellular localization of $\mathrm{Br}-\mathrm{C} 4$ and I-C4 squaraine dyes inside HT-1080 cells was observed by confocal analysis between squaraine dyes and cellular mitochondria. $\mathrm{Br}-\mathrm{C} 4$ and I-C4 photodynamic treatment lead to an increase in ROS production in the very first few minutes after treatment. This was then followed by the simultaneous induction of necrotic events 3 $\mathrm{h}$ after treatment and a drastic reduction in cytochrome $\mathrm{c}$.

In summary, the results described herein suggest that squaraine dyes can be considered promising, innovative photosensitizers for use in photodynamic anticancer treatment. The easiness of preparation and the possibility to provide a large variety of molecules with different structural properties will allow a wide and complete SAR study. 


\section{EXPERIMENTAL}

\subsection{Chemistry}

All solvents and reagents (i.e. (4-bromophenyl)hydrazine, 1a; (4-iodophenyl)hydrazine, 1b; 2,3,3-trimethyl-3H-indole, 3c) were purchased from commercial sources and used as received without further purification, unless otherwise stated. All microwave reactions were performed in a single-mode Biotage Initiator 2.5. LC-HRMS analyses were accomplished with an Ultimate 3000 HPLC instrument (Dionex, Milan, Italy) coupled to an LTQ Orbitrap instrument at a resolution of $30000(500 \mathrm{~m} / \mathrm{z}$ FWHM) in FTMS mode (Thermo Scientific, Rodano, Italy) with an APCI interface. ${ }^{1} \mathrm{H}$ NMR spectra were recorded on a Bruker Advance 200 and calibrated to the residual solvent peak. All chemical shifts are in ppm and coupling constants are in Hertz (Hz). UV-Vis-NIR spectra were recorded on a Shimadzu UV-1700 spectrometer. Spectroscopic grade solvents (Chromasolv) from Sigma Aldrich were used for all spectroscopic measurements.

\subsubsection{Synthesis}

The starting 5-substitute 2,3,3-trimethylindolium (2a-b) was readily obtained via the condensation of benzohydrazine substitute 1a-b with 3-methylbutan-2-one in glacial acetic, acid as previously reported $[15,16]$ (see Scheme 2 ). The obtained indolenines were then quaternarized. In a typical experiment, an appropriate iodo-alkane (1:4 molar ratio) was placed into a reaction vial with $\mathrm{CH}_{3} \mathrm{CN}$ and 2a-b. The vessel was then sealed with a crimp cap and heated in the microwave system at $155^{\circ} \mathrm{C}$ for $35 \mathrm{~min}$, according to a previously published procedure [15]. The solid formed was isolated by filtration and repeatedly washed under stirring with diethyl ether $(3 \times 200 \mathrm{~mL})$ and then filtered, giving pure products $\mathbf{3 a - b}$.

A suspension of squaric acid $(0.5 \mathrm{mmol})$ and either indolenine or indolium molecules 3 (1 mmol) in a 1:1 mixture of butanol:toluene $(2 \mathrm{ml})$ was heated at $160^{\circ} \mathrm{C}$ in the microwave reactor. The deep blue-green mixture was cooled to room temperature and a shiny purple precipitate was formed. The 
solvent was removed and the precipitate was washed a few times with diethyl ether. Squaraines were obtained in $41-82 \%$ yields.

4.1.1.1. 2-[[3-[(1,3-dihydro-3,3-dimethyl-2H-indol-2-ylidene)methyl]-2-hydroxy-4-oxo-2cyclobuten-1-ylidene]methyl]-3,3-trimethyl-3H-indole (SQ-NH) [27,28].

2,3,3-trimethyl-3H-indole (3c) $(159.2 \mathrm{mg})$ and squaric acid $(57.0 \mathrm{mg})$ in butanol/toluene solution $(1: 1,2 \mathrm{ml})$ at $160^{\circ} \mathrm{C}$ for $20 \mathrm{~min}$ gave $81 \mathrm{mg}$ of SQ-NH, $0.21 \mathrm{mmol} ., 41 \%$ yield.

${ }^{1} \mathrm{H}$ NMR $\left(\mathrm{CD}_{3} \mathrm{OD}-d_{4}\right) \delta: 7.41-7.24(\mathrm{~m}, 8 \mathrm{H}), 4.87(\mathrm{~s}, 2 \mathrm{H}), 1.31(\mathrm{~s}, 12 \mathrm{H})$

HRMS (ESI) calcd for $\mathrm{C}_{26} \mathrm{H}_{24} \mathrm{~N}_{2} \mathrm{O}_{2}[\mathrm{M}]^{+} 397.1838$, found 397.1958

4.1.1.2. 5-bromine-2-[[3-[(1,3-dihydro-3,3-dimethyl-2H-indol-2-ylidene)methyl]-2-hydroxy-4-oxo2-cyclobuten-1-ylidene] methyl]-5-bromine-3,3-trimethyl-3H-indole (Br-NH) [15].

5-bromine-2,3,3-trimethyl-3H-indole (3a) $(238.1 \mathrm{mg})$ and squaric acid (57.0 $\mathrm{mg})$ in butanol/toluene solution $(1: 1,2 \mathrm{ml})$ at $160^{\circ} \mathrm{C}$ for $30 \mathrm{~min}$ gave $183 \mathrm{mg}$ of $\mathrm{Br}-\mathrm{NH}, 0.33 \mathrm{mmol}, 66 \%$ yield.

${ }^{1} \mathrm{H} \mathrm{NMR}\left(\mathrm{CDCl}_{3}-d_{1}\right) \delta: 7.44(4 \mathrm{H}, \mathrm{m}), 6.98(2 \mathrm{H}, \mathrm{m}), 5.44-5.40(2 \mathrm{H}, \mathrm{m}), 1.39(12 \mathrm{H}, \mathrm{s})$

HRMS (ESI) calcd for $\mathrm{C}_{26} \mathrm{H}_{22} \mathrm{Br}_{2} \mathrm{~N}_{2} \mathrm{O}_{2}[\mathrm{M}]^{+}$553.0048, found 553.0159

4.1.1.3. 5-bromine-2-[[3-[(1,3-dihydro-3,3-dimethyl-1-ethyl-2H-indol-2-ylidene)methyl]-2hydroxy-4-oxo-2-cyclobuten-1-ylidene]methyl]- 5-bromine-3,3-trimethyl-1- ethyl-3H-indolium (BrC2) [15].

5-bromine-2,3,3-trimethyl-1-ethyl-3H-indolium iodide salt (3a-C2) (394.1 mg) and squaric acid (57.0 mg) in butanol/toluene solution $(1: 1,2 \mathrm{ml})$ at $160^{\circ} \mathrm{C}$ for $30 \mathrm{~min}$ gave $250 \mathrm{mg}$ of $\mathbf{B r}-\mathbf{C 2}, 0.41$ mmol, $82 \%$ yield.

${ }^{1} \mathrm{H}$ NMR $\left(\mathrm{CDCl}_{3}\right) \delta: 7.45(2 \mathrm{H}, \mathrm{s}), 7.43(2 \mathrm{H}, \mathrm{d}, \mathrm{J}=8 \mathrm{~Hz}), 6.86(2 \mathrm{H}, \mathrm{d} \mathrm{J}=8 \mathrm{~Hz}), 5.96(2 \mathrm{H}, \mathrm{s})$, 4.05(4H, m), $1.77(12 \mathrm{H}, \mathrm{s}), 1.38(6 \mathrm{H}, \mathrm{t}, \mathrm{J}=7 \mathrm{~Hz})$

HRMS (ESI) calcd for $\mathrm{C}_{30} \mathrm{H}_{30} \mathrm{Br}_{2} \mathrm{~N}_{2} \mathrm{O}_{2}[\mathrm{M}]^{+}$609.0674, found 609.0824 

hydroxy-4-oxo-2-cyclobuten-1-ylidene]methyl]- 5-bromine-3,3-trimethyl-1- butyl-3H-indolium (BrC4) $[15]$.

5-bromine-2,3,3-trimethyl-1-butyl-3H-indolium iodide salt (3a-C4) (422.1 mg) and squaric acid (57.0 $\mathrm{mg})$ in butanol/toluene solution $(1: 1,2 \mathrm{ml})$ at $160^{\circ} \mathrm{C}$ for $45 \mathrm{~min}$ gave $230 \mathrm{mg}$ of $\mathbf{B r}-\mathbf{C 4}, 0.35$ mmol, 69\% yield.

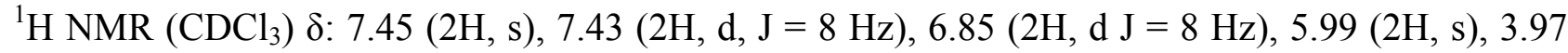
(4H, bt), 1.77 (12H, s), 1.69 (4H, m), $1.52(4 \mathrm{H}, \mathrm{m}), 0.98(6 \mathrm{H}, \mathrm{t}, \mathrm{J}=7 \mathrm{~Hz})$ HRMS (ESI) calcd for $\mathrm{C}_{34} \mathrm{H}_{38} \mathrm{Br}_{2} \mathrm{~N}_{2} \mathrm{O}_{2}[\mathrm{M}]^{+}$665.1300, found 665.1448

4.1.1.5. 5-iodine-2-[[3-[(1,3-dihydro-3,3-dimethyl-2H-indol-2-ylidene)methyl]-2-hydroxy-4-oxo-2cyclobuten-1-ylidene]methyl]-5-iodine-3,3-trimethyl-3H-indole (I-NH).

5-iodine-2,3,3-trimethyl-3H-indole (3b) $(285.1 \mathrm{mg})$ and squaric acid $(57.0 \mathrm{mg})$ in butanol/toluene solution $(1: 1,2 \mathrm{ml})$ at $160^{\circ} \mathrm{C}$ for $30 \mathrm{~min}$ gave $181 \mathrm{mg}$ of I-NH, $0.28 \mathrm{mmol}, 56 \%$ yield.

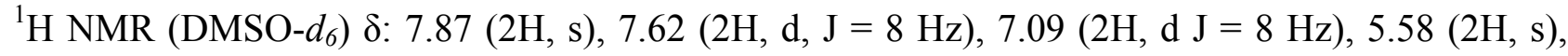
$1.43(12 \mathrm{H}, \mathrm{s})$

HRMS (ESI) calcd for $\mathrm{C}_{26} \mathrm{H}_{22} \mathrm{I}_{2} \mathrm{~N}_{2} \mathrm{O}_{2}[\mathrm{M}]^{+}$647.9771, found 647.9836

4.1.1.6. 5-iodine-2-[[3-[(1,3-dihydro-3,3-dimethyl-1-ethyl-2H-indol-2-ylidene)methyl]-2-hydroxy4-oxo-2-cyclobuten-1-ylidene]methyl]- 5-iodine-3,3-trimethyl-1-ethyl-3H-indolium (I-C2)

5-iodine-2,3,3-trimethyl-1-ethyl-3H-indolium iodide salt (3b-C2) (441.1 mg) and squaric acid (57.0 $\mathrm{mg}$ ) in butanol/toluene solution $(1: 1,2 \mathrm{ml})$ at $160^{\circ} \mathrm{C}$ for $30 \mathrm{~min}$ gave $176 \mathrm{mg}$ of I-C2, $0.25 \mathrm{mmol}$, $49 \%$ yield.

${ }^{1} \mathrm{H}$ NMR (DMSO- $\left.d_{6}\right) \delta: 7.90(2 \mathrm{H}, \mathrm{s}), 7.68(2 \mathrm{H}, \mathrm{d}, \mathrm{J}=8 \mathrm{~Hz}), 7.18(2 \mathrm{H}, \mathrm{d} \mathrm{J}=8 \mathrm{~Hz}), 5.77(2 \mathrm{H}, \mathrm{s})$, 4.09 (broad, 4H, m), $1.66(12 \mathrm{H}, \mathrm{s}), 1.25(6 \mathrm{H}, \mathrm{t}, \mathrm{J}=7 \mathrm{~Hz})$

HRMS (ESI) calcd for $\mathrm{C}_{30} \mathrm{H}_{30} \mathrm{I}_{2} \mathrm{~N}_{2} \mathrm{O}_{2}[\mathrm{M}]^{+} 705.0397$, found 705.0545 
4.1.1.7. 5-iodine-2-[[3-[(1,3-dihydro-3,3-dimethyl-1-butyl-2H-indol-2-ylidene)methyl]-2-hydroxy4-oxo-2-cyclobuten-1-ylidene] methyl]- 5-butine-3,3-trimethyl-1- butyl-3H-indolium (I-C4).

5-iodine-2,3,3-trimethyl-1-butyl-3H-indolium iodide salt (3b-C4) (469.1 $\mathrm{mg})$ and squaric acid (57.0 $\mathrm{mg})$ in butanol/toluene solution $(1: 1,2 \mathrm{ml})$ at $160^{\circ} \mathrm{C}$ for $45 \mathrm{~min}$ gave $208 \mathrm{mg}$ of I-C4, $0.29 \mathrm{mmol}$, $59 \%$ yield.

${ }^{1} \mathrm{H}$ NMR (DMSO-d $\left.d_{6}\right) \delta: 7.91(2 \mathrm{H}, \mathrm{s}), 7.68(2 \mathrm{H}, \mathrm{d}, \mathrm{J}=8 \mathrm{~Hz}), 7.19(2 \mathrm{H}, \mathrm{d} \mathrm{J}=8 \mathrm{~Hz}), 5.79(2 \mathrm{H}, \mathrm{s})$, $4.05(4 \mathrm{H}, \mathrm{m}), 1.66(12 \mathrm{H}, \mathrm{s}), 1.53(4 \mathrm{H}, \mathrm{m}), 1.39(4 \mathrm{H}, \mathrm{m}), 0.93(6 \mathrm{H}, \mathrm{t})$

HRMS (ESI) calcd for $\mathrm{C}_{34} \mathrm{H}_{38} \mathrm{I}_{2} \mathrm{~N}_{2} \mathrm{O}_{2}[\mathrm{M}]^{+} 761.1023$, found 761.1176

\subsubsection{Evaluation of singlet oxygen generation ability}

Solutions of DPBF $(20 \mu \mathrm{M})$ and dyes $(5 \mu \mathrm{M})$ were prepared in phosphate buffer $(2 \mathrm{mM}, \mathrm{pH}$ 7.4) with $1 \%$ of DMSO. Each solution was placed in a $1 \mathrm{~cm}$ quartz cell and irradiated in an aerated solar box with a $250 \mathrm{~W}$ lamp at various time intervals. Light was filtered in an optical filter with a $515 \mathrm{~nm}$ cut-off.

\subsubsection{Biological assays}

\subsubsection{Cell line and culturing}

The HT-1080 human fibrosarcoma cell line (ATCC, Rockville, MD, USA) was cultured in Minimum Essential Medium Eagle (EMEM) supplemented with $2 \mathrm{mM}$ L-glutamine, $100 \mathrm{UI} / \mathrm{mL}$ penicillin, $100 \mu \mathrm{g} / \mathrm{mL}$ streptomycin and 10\% fetal bovine serum (Sigma Aldrich, St Louis, MO, USA). Cell lines were kept in a humidified atmosphere of $5 \% \mathrm{CO}_{2}$ air at $37^{\circ} \mathrm{C}$.

The effect that squaraine dyes (SQ-NH, Br-NH, I-NH, Br-C2, I-C2, Br-C4 and I-C4) had on HT-1080 cell growth was evaluated using a WST-1 cell proliferation assay (Roche Applied Science, Penzberg, Germany). Squaraine dyes were diluted in 100\% dimethyl sulfoxide (DMSO, 
Sigma Aldrich) at a final concentration of $2 \mathrm{mM}$. The obtained solutions were then briefly vortexed and aliquots were stored in tightly sealed dark vials at $-20^{\circ} \mathrm{C} .1 \times 10^{3} \mathrm{HT}-1080$ cells were seeded in $100 \mu \mathrm{L}$ of growth medium in replicates $(\mathrm{n}=8)$ in a 96-well culture plate (TPP, Trasadingen, Switzerland). After $24 \mathrm{~h}$ of cell growth, the medium was removed and the cells incubated with in experimental media of differing squaraine concentrations $(0.25,0.50,1.00$ and $10 \mu \mathrm{M})$. The WST-1 reagent (Roche Applied Science) $(10 \mu \mathrm{L} / 100 \mu \mathrm{L})$ was added, at 24, 48 and $72 \mathrm{~h}$, and plates were incubated at $37^{\circ} \mathrm{C}$ in $5 \% \mathrm{CO}_{2}$ for $90 \mathrm{~min}$. Well absorbance was measured at 450 and $620 \mathrm{~nm}$ (reference wavelength) in the microplate reader Asys UV340 (Biochrom, Cambridge, UK). Cell proliferation data were expressed as the ratio between the absorbance of treated and untreated cells.

\subsubsection{In vitro photodynamic treatment}

The HT-1080 in the exponential phase were preincubated in the dark for $24 \mathrm{~h}$ in a culture medium containing squaraine derivatives at $1 \mu \mathrm{M}$, i.e. the maximum non-cytotoxic concentration tested. Cells were removed from the flask after incubation using a $0.05 \%$ trypsin- $0.02 \%$ EDTA solution (Sigma Aldrich) and normalized to $1.5 \times 10^{5}$ cells in $1 \mathrm{~mL}$ of phosphate buffered solution (PBS, Sigma Aldrich) in polystyrene tubes (TPP). The light emitting source of the system is based on a light beam (LB), specifically a red LED with a wavelength of $636 \mathrm{~nm}$ and energy fluency rates adjusted to $15 \mathrm{~mW} / \mathrm{cm}^{2}$. In particular, cellular suspensions were illuminated for $20 \mathrm{~min}$ in a dark box. After PDT, $1.5 \times 10^{3}$ cells were plated in a 96-well culture plate (TPP). Cellular proliferation was evaluated at 24, 48 and $72 \mathrm{~h}$ using the WST-1 (Roche Applied Science) cell proliferation reagent $(10 \mu \mathrm{L} / 100 \mu \mathrm{L})$. Cell proliferation data are expressed as the ratio between the absorbance of treated and untreated cells.

\subsubsection{Flow cytometric analysis}

Squaraine dye cellular uptake analysis was carried out on C6 flow cytometry equipment (Accuri Cytometers, Milano, Italy). Briefly, 6 × $10^{4}$ cells were plated in 6 -well culture plates (TPP) 
and incubated with squaraine dyes $(1 \mu \mathrm{M})$ for 3,6 and $24 \mathrm{~h}$. Cells were detached after each incubation period using a $0.05 \%$ trypsin- $0.02 \%$ EDTA solution (Sigma Aldrich) and re-suspended in $300 \mu \mathrm{L}$ PBS (Sigma Aldrich). They were then run on the C6 flow cytometer (Accuri Cytometers), which considered 10,000 events, using $640 \mathrm{~nm}$ excitation to measure the intracellular squaraines. Intracellular fluorescence is expressed as integrated median fluorescence intensity (iMFI). This is the product of the frequency of cells that are positive to squaraine dye and the median fluorescence intensity of the cells. The most suitable squaraine concentration for the study was chosen according to iMFi ratio. Results are expressed in iMFI ratio, i.e., the ratio between the iMFI of treated and untreated cells.

Reactive oxygen species (ROS) production was performed 1, 5, 15, 30, 45, 60 min after PDT. Cells were incubated with $10 \mu \mathrm{M}$ of 2',7'-dichlorofluorescein diacetate (DCFH-DA) (Sigma Aldrich) for $30 \mathrm{~min}, 24 \mathrm{~h}$ after incubation with squaraine dyes (Br-C4 or I-C4, $1 \mu \mathrm{M})$. After incubation, cells were washed with PBS, trypsinzed and $1.5 \times 10^{5}$ cells were collected in $1 \mathrm{ml}$ of PBS and treated with a $15 \mathrm{~mW} / \mathrm{cm}^{2} \mathrm{LB}$ for $20 \mathrm{~min}$. Cells were analyzed after treatment by a C6 flow cytometer (Accuri Cytometers), which evaluated 10,000 events. ROS production was performed and the iMFI, which is the product of the frequency of ROS-producing cells and the median fluorescence intensity of the cells, was evaluated.

Cell death was evaluated using the Dead Cell Apoptosis Kit with Annexin V-Alexa Fluor ${ }^{\circledR}$ 488 and Propidium Iodide (PI) (Life Technologies, Milano, Italy). Briefly, $2.0 \times 10^{5}$ HT-1080 cells were incubated for $24 \mathrm{~h}$ with Br-C4 or I-C4 $(1 \mu \mathrm{M})$, and then treated with $\mathrm{LB}$ at $15 \mathrm{~mW} / \mathrm{cm}^{2}$ for 20 min. Six hours after treatment, cells were detached with trypsin and washed with PBS (Sigma Aldrich), centrifuged at $375 r c f$ for $5 \mathrm{~min}$ and then re-suspended in $1 \mathrm{x}$ annexin-binding buffer and stained with Annexin V Alexa Fluor and PI. Samples were run on a C6 flow cytometer (Accuri Cytometers) at $488 \mathrm{~nm}$ excitation to measure Annexin V-Alexa Fluor ${ }^{\circledR}$ and at $530 \mathrm{~nm}$ to measure PI. 10,000 events were considered for the analysis and any cell debris with low forward scatter (FSC) and side scatter (SSC) were excluded. The two different stainings allowed us to distinguish 
the apoptotic (Annexin V-Alexa Fluor ${ }^{\circledR}$ positive) and necrotic cells (Annexin V-Alexa Fluor ${ }^{\circledR}$ and PI positive) from viable cells (Annexin V-Alexa Fluor ${ }^{\circledR}$ and PI negative). All analyses were performed on a FCS Express 4 (BD Bioscience, Milano, Italy).

DNA damage was evaluated 30 min after PDT treatment using a DNA Damage - AP site Assay kit (Cell Based) (Abcam Company, Burlingame, California), and according to manufacturer's instructions. In particular, an aldehyde reactive probe (ARP), that reacts specifically with the aldehyde groups that are formed by protein or DNA modification, was used to assess oxidative DNA damage. Aldehyde sites on both proteins and DNA were converted to biotin-tagged aldehyde sites, using an excess of ARP, and detected using avidin-conjugated reporters. Briefly, $5 \times$ $10^{5}$ cells were incubated with Br-C4 or I-C4 $1 \mu \mathrm{M}$ for $24 \mathrm{~h}$ and then treated with PDT. The samples were run on a C6 flow cytometer at $488 \mathrm{~nm}$ to measure the avidin signal. Any cell debris with low FSC and SSC were excluded from the analyses and a total of 10000 events were analyzed.

Cytochrome c was analyzed 0.5 and $3 \mathrm{~h}$ after PDT treatment. Briefly, $5 \times 10^{5}$ cells were incubated with $1 \mu \mathrm{M} \mathrm{Br}-\mathrm{C} 4$ or I-C4 for $24 \mathrm{~h}$ and then treated with PDT. Cytosolic cytochrome c content was then ascertained in supernatants from the selectively permeabilized cells using an enzyme-linked immunosorbent assay (eBioscience, San Diego, CA, USA), according to manufacturer's instructions. The concentration of cytochrome c (ng/mg) was then calibrated from a standard curve based on reference standards.

\subsubsection{Confocal analysis of squaraine dyes}

In order to understand whether squaraine dyes colocalize with cell mitochondria, MitoTracker Green (Life Technologies), a mitochondria-specific probe, was used. Briefly, $1.0 \times 10^{4}$ cells were left to attach for $48 \mathrm{~h}$ on glass coverslips in a 24 -well plate (TPP) and then incubated with growth medium with squaraine dyes, Br-C4 or I-C4 $1 \mu \mathrm{M}$, for $24 \mathrm{~h}$. After incubation, the cells were washed and then incubated with MitoTracker Green (100 nM) for $45 \mathrm{~min}$. Prior to 
visualization, excess probe was washed off via rinsing four times in PBS and cells were fixed in paraformaldehyde. Coverslips were then mounted onto a glass slide and observed using an Olympus Fluoview 200 laser scanning confocal system (Olympus America Inc., Melville, NY, USA) mounted on an inverted IX70 Olympus microscope, equipped with 60X Uplan F1 (NA 1.25) and 100X Uplan Fl (NA 1.30) oil-immersion objectives. MitoTracker Green was excited with a Ar/Kr laser at $488 \mathrm{~nm}$ and squaraine dyes by at 568 in order to simultaneously detect the probes. Images acquired at 60x magnification were processed and analysed with ImageJ software (Rasband,W.S., U.S. National Institutes of Health, Bethesda, MA).

\subsubsection{Real-time polymerase chain reaction (RT-PCR)}

In order to evaluate the effect of PDT on mRNA gene expression, total RNA was isolated from HT-1080 at $0.5,3 \mathrm{~h}$ and $24 \mathrm{~h}$ after photodynamic treatment. Briefly, $2.0 \times 10^{5}$ cells were collected in a RNA Cell Protection Reagent (Qiagen, Milano, Italy) and stored at $-80{ }^{\circ} \mathrm{C}$. Total RNA was obtained using the RNeasy Plus Mini kit (Qiagen) and total RNA concentration $(\mu \mathrm{g} / \mathrm{mL})$ was determined using a Qubit fluorometer (Life Technologies) and the Quant-IT RNA Assay Kit (Invitrogen, Milano, Italy). Calibration was performed using a two-point standard curve, according to manufacturer's instructions.

Real-time RT-PCR analysis was carried out using $150 \mathrm{ng}$ of total RNA that was reverse transcribed in $20 \mu \mathrm{L}$ cDNA reaction volume using the QuantiTect Reverse Transcription Kit (Qiagen). In accordance with manufacturer's instructions, $12.5 \mathrm{ng}$ of cDNA was used for each 10 $\mu \mathrm{L}$ real time RT-PCR reaction. Quantitative RT-PCR was performed using a SsoFast EvaGreen (Bio-Rad, Milano, Italy) and after the QuantiTect Primer Assay (Qiagen), APAF1 (Cat No QT00092358), BAX (Cat No QT00062090), BCL2 (Cat No QT00031192), GPX1 (Cat No QT00203392), NQO1( Cat No QT00050281), RRN18S (Cat No QT00199367), SOD2 (Cat No QT1008693), TP53 (Cat No QT00060235) were used. The transcript of the reference 18S ribosomal RNA (RRN18S) was used to normalize mRNA data and real-time PCR was performed using a 
MiniOpticon Real Time PCR system (Bio-Rad). The PCR protocol conditions were as follows: HotStarTaq DNA polymerase activation step at $95^{\circ} \mathrm{C}$ for 30 seconds, followed by 40 cycles at $95^{\circ} \mathrm{C}$ for 5 seconds and $55^{\circ} \mathrm{C}$ for 10 seconds. All runs were performed on at least three independent cDNA preparations per sample and all samples were run in duplicate. At least two non-template controls were included in all PCR runs. Quantification data analyses were performed using Bio-Rad CFX Manager Software version 3.1 (Bio-Rad), according to manufacturer's instruction. These analyses were performed in compliance with MIQE guidelines (Minimum Information for Publication of Quantitative Real-time PCR Experiment).

\subsubsection{Statistical analysis}

Data are shown as average values of three independent experiments \pm standard deviation. Statistical analyses were performed using Graph-Pad Prism 5.0 software (La Jolla, CA, USA); oneway and two-way analyses of variance and Bonferroni's test were used to calculate the threshold of significance. Statistical significance was set at $\mathrm{p}<0.05$.

\section{ACKNOWLEDGEMENTS}

This work has been funded by MIUR NANOMED project (PRIN 2010-2011, 2010FPTBSH_003) and by the University of Torino (Grant "Ricerca Locale 2014"). The authors gratefully thank Prof. Pierluigi Civera for his outstanding support. S.E. and N.B. thank MIUR for partial financial support of their research grants. 


\section{REFERENCES}

[1] A.M. Rkein, D.M. Ozog, Photodynamic therapy, Dermatol. Clin. 32 (2014) 415-425. doi:10.1016/j.det.2014.03.009.

[2] W.M. Sharman, C.M. Allen, J.E. van Lier, Photodynamic therapeutics: basic principles and clinical applications, Drug Discov. Today. 4 (1999) 507-517. doi:10.1016/S13596446(99)01412-9.

[3] K.R. Weishaupt, C.J. Gomer, T.J. Dougherty, Identification of singlet oxygen as the cytotoxic agent in photoinactivation of a murine tumor., Cancer Res. 36 (1976) 2326-2329.

[4] J.P. Celli, B.Q. Spring, I. Rizvi, C.L. Evans, K.S. Samkoe, S. Verma, et al., Imaging and photodynamic therapy: Mechanisms, monitoring, and optimization, Chem. Rev. 110 (2010) 2795-2838. doi:10.1021/cr900300p.

[5] A.B. Ormond, H.S. Freeman, Dye sensitizers for photodynamic therapy, Materials (Basel). 6 (2013) 817-840. doi:10.3390/ma6030817.

[6] M.R. Detty, S.L. Gibson, S.J. Wagner, Current clinical and preclinical photosensitizers for use in photodynamic therapy, J. Med. Chem. 47 (2004) 3897-3915. doi:10.1021/jm040074b.

[7] R.R. Allison, C.H. Sibata, Oncologic photodynamic therapy photosensitizers: A clinical review, Photodiagnosis Photodyn. Ther. 7 (2010) 61-75. doi:10.1016/j.pdpdt.2010.02.001.

[8] J. Park, G. Viscardi, C. Barolo, N. Barbero, Near-Infrared Sensitization in Dye-Sensitized Solar Cells., Chimia (Aarau). 67 (2013) 129-135.

http://www.ncbi.nlm.nih.gov/pubmed/23574951.

[9] a) J. Park, N. Barbero, J. Yoon, E. Dell'Orto, S. Galliano, R. Borrelli, et al., Panchromatic symmetrical squaraines: a step forward in the molecular engineering of low cost bluegreenish sensitizers for dye-sensitized solar cells, Phys. Chem. Chem. Phys. 16 (2014) 24173-24177. doi:10.1039/C4CP04345F; b) J. Park, C. Barolo, F. Sauvage, N. Barbero, C. Benzi, P. Quagliotto, et al., Symmetric vs. asymmetric squaraines as photosensitisers in mesoscopic injection solar cells: a structure-property relationship study, Chem. Commun. 48 (2012) 2782. doi:10.1039/c2cc17187b; c) C. Magistris, S. Martiniani, N. Barbero, J. Park, C. Benzi, A. Anderson, et al., Near-infrared absorbing squaraine dye with extended $\pi$ conjugation for dye-sensitized solar cells, Renew. Energy. 60 (2013) 672-678.

[10] N. Barbero, S. Visentin, G. Viscardi, The different kinetic behavior of two potential photosensitizers for PDT, J. Photochem. Photobiol. A Chem. 299 (2015) 38-43. doi:10.1016/j.jphotochem.2014.11.002.

[11] R.R. Avirah, D.T. Jayaram, N. Adarsh, D. Ramaiah, Squaraine dyes in PDT: from basic design to in vivo demonstration, Org. Biomol. Chem. 10 (2012) 911. doi:10.1039/c1ob06588b.

[12] D. Ramaiah, A. Joy, N. Chandrasekhar, N. V Eldho, S. Das, M. V George, Halogenated Squaraine Dyes as Potential Photochemotherapeutic Agents . Synthesis and Study of 
Photophysical Properties and Quantum Efficiencies of Singlet Oxygen Generation, Synthesis (Stuttg). 65 (1997) 783-790. doi:10.1111/j.1751-1097.1997.tb01925.x.

[13] V. Rapozzi, L. Beverina, P. Salice, G. a. Pagani, M. Camerin, L.E. Xodo, Photooxidation and phototoxicity of $\pi$-extended squaraines, J. Med. Chem. 53 (2010) 2188-2196.

doi:10.1021/jm901727j.

[14] L. Beverina, M. Sassi, Twists and turns around a square: The many faces of Squaraine chemistry, Synlett. 25 (2014) 477-490. doi:10.1055/s-0033-1340482.

[15] N. Barbero, C. Magistris, J. Park, D. Saccone, P. Quagliotto, R. Buscaino, et al., Microwaveassisted synthesis of near-infrared fluorescent indole-based squaraines, Org. Lett. (under revisions).

[16] E. Cuevas Creencia, M. Tsukamoto, T. Horaguchi, One-Pot Three-Component Mild Synthesis of 2-Aryl-3-(9-alkylcarbazol-3-yl)thiazolin-4-ones, J. Heterocycl. Chem. 48 (2011) 1095 -1102. doi:10.1002/jhet.

[17] E. A. Owens, N. Bruschi, J.G. Tawney, M. Henary, A microwave-assisted and environmentally benign approach to the synthesis of near-infrared fluorescent pentamethine cyanine dyes, Dye. Pigment. 113 (2015) 27-37. doi:10.1016/j.dyepig.2014.07.035.

[18] J. Chen, R.F. Winter, Studies on a vinyl ruthenium-modified squaraine dye: Multiple visible/near-infrared absorbance switching through dye- and substituent-based redox processes, Chem. - A Eur. J. 18 (2012) 10733-10741. doi:10.1002/chem.201200800.

[19] A. Levitz, S.T. Ladani, D. Hamelberg, M. Henary, Synthesis and effect of heterocycle modification on the spectroscopic properties of a series of unsymmetrical trimethine cyanine dyes, Dye. Pigment. 105 (2014) 238-249. doi:10.1016/j.dyepig.2014.02.009.

[20] U. Mayerhöffer, B. Fimmel, F. Würthner, Bright near-infrared fluorophores based on squaraines by unexpected halogen effects., Angew. Chem. Int. Ed. Engl. 51 (2012) 164-7. doi:10.1002/anie.201107176.

[21] Y. Prostota, O.D. Kachkovsky, L. V. Reis, P.F. Santos, New unsymmetrical squaraine dyes derived from imidazo[1,5-A]pyridine, Dye. Pigment. 96 (2013) 554-562. doi:10.1016/j.dyepig.2012.10.006.

[22] L. Beverina, M. Crippa, M. Landenna, R. Ruffo, P. Salice, F. Silvestri, et al., Assessment of water-soluble $\pi$-extended squaraines as one- and two-photon singlet oxygen photosensitizers: Design, synthesis, and characterization, J. Am. Chem. Soc. 130 (2008) 1894-1902. doi:10.1021/ja075933a.

[23] P. Mroz, A. Yaroslavsky, G.B. Kharkwal, M.R. Hamblin, Cell death pathways in photodynamic therapy of cancer, Cancers (Basel). 3 (2011) 2516-2539. doi: $10.3390 /$ cancers 3022516 .

[24] M.S. Soumya, K.M. Shafeekh, S. Das, A. Abraham, Symmetrical diiodinated squaraine as an efficient photosensitizer for PDT applications: Evidence from photodynamic and toxicological aspects, Chem. Biol. Interact. 222 (2014) 44-49. doi:10.1016/j.cbi.2014.08.006. 
[25] D. Ramaiah, I. Eckert, K.T. Arun, L. Weidenfeller, B. Epe, Squaraine dyes for photodynamic therapy: mechanism of cytotoxicity and DNA damage induced by halogenated squaraine dyes plus light (>600 nm)., Photochem. Photobiol. 79 (2004) 99-104. doi:10.1562/00318655(2004)79<99:SDFPTM>2.0.CO;2.

[26] D.J. Granville, C.M. Carthy, H. Jiang, G.C. Shore, B.M. McManus, D.W.C. Hunt, Rapid cytochrome c release, activation of caspases 3, 6, 7 and 8 followed by Bap31 cleavage in HeLa cells treated with photodynamic therapy, FEBS Lett. 437 (1998) 5-10. doi:10.1016/S0014-5793(98)01193-4.

[27] R. Borrelli, S. Ellena, C. Barolo, Theoretical and experimental determination of the absorption and emission spectra of a prototypical indolenine-based squaraine dye., Phys. Chem. Chem. Phys. 16 (2014) 2390-8. doi:10.1039/c3cp54298j.

[28] G. Smith, D.E. Lynch, 2-[(3,3-Dimethylindolin-2-ylidene)methyl]-4-[(3,3-dimethyl-3 H indol-1-ium-2-yl)methylidene]-3-oxocyclobut-1-en-1-olate chloroform disolvate, Acta Crystallogr. Sect. E Struct. Reports Online. 69 (2013) o786-o787. doi:10.1107/S1600536813010386. 

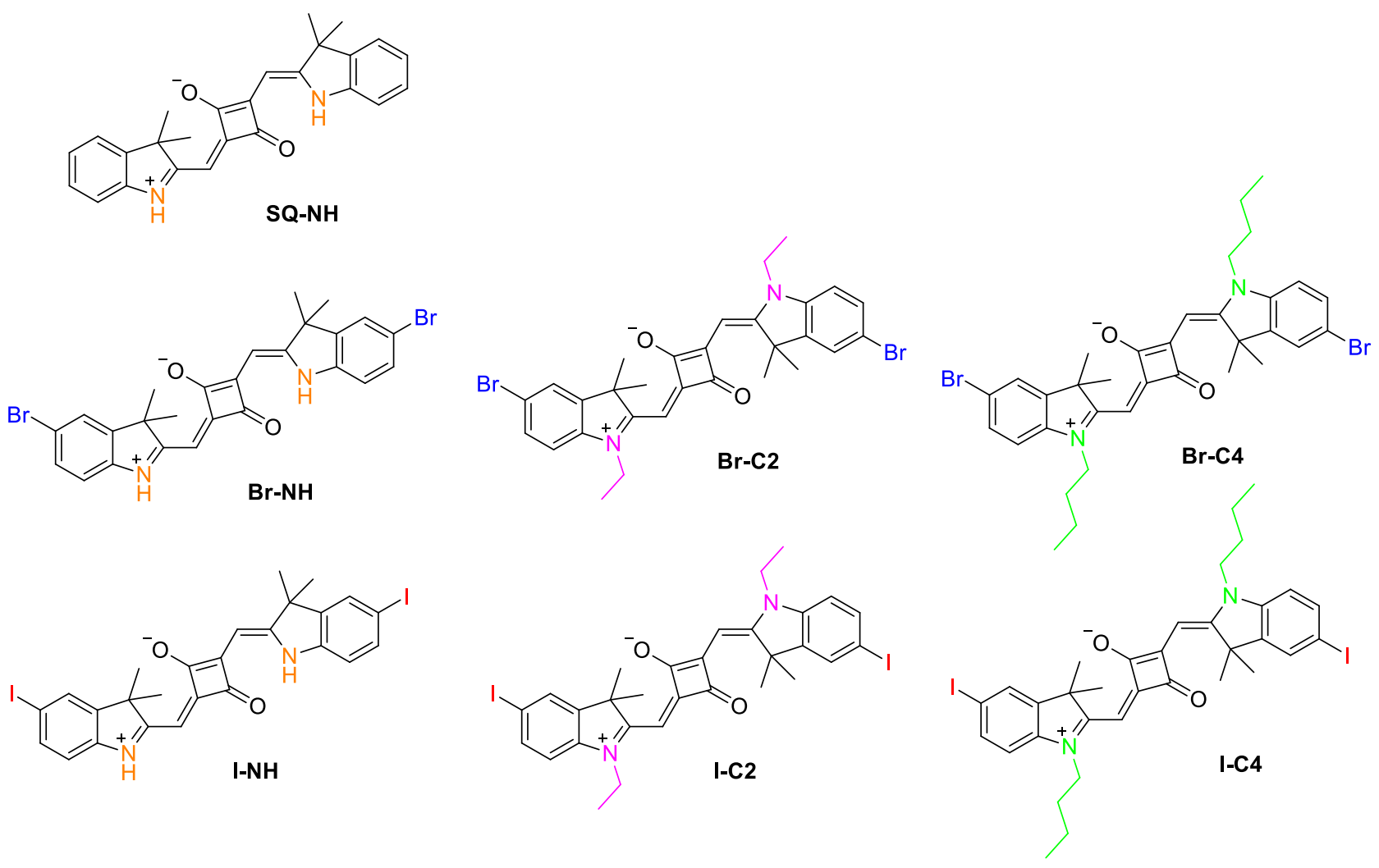

Scheme 1. Structures of the synthesized compounds. 


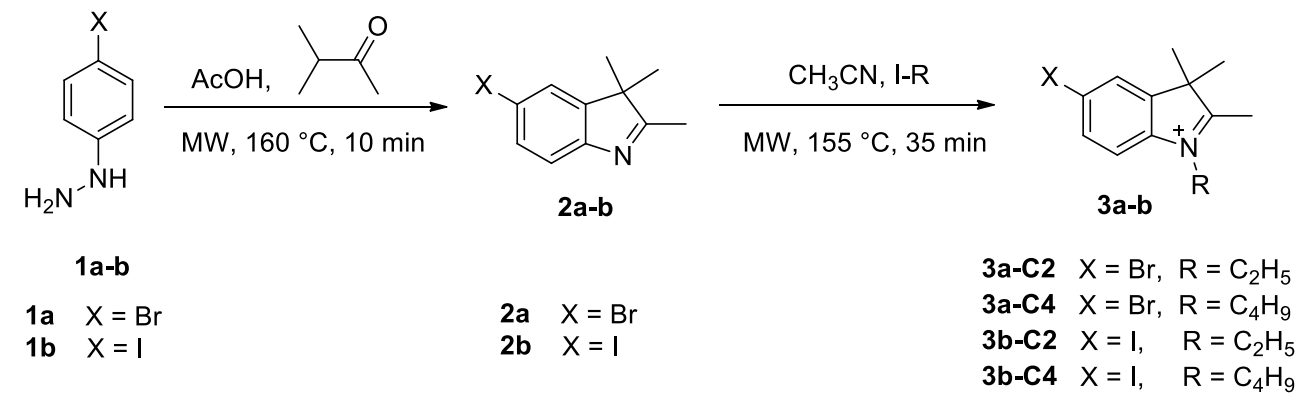

Scheme 2. Synthesis and quaternization of indolenines. 


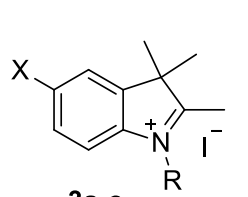

3a-c

3a $\mathrm{X}=\mathrm{Br}, \mathrm{R}=\mathrm{H}$

3a-C2 $\mathrm{X}=\mathrm{Br}, \mathrm{R}=\mathrm{C}_{2} \mathrm{H}_{5}$

3a-C4 $X=\mathrm{Br}, \mathrm{R}=\mathrm{C}_{4} \mathrm{H}_{9}$

3b $\quad X=I, \quad R=H$

3b-C2 $X=I, \quad R=\mathrm{C}_{2} \mathrm{H}_{5}$

3b-C4 $X=I, \quad R=\mathrm{C}_{4} \mathrm{H}_{9}$

3c $\quad X=H, \quad R=H$

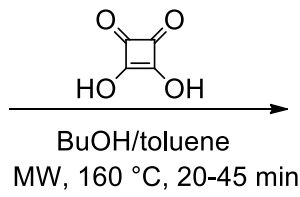

$\mathrm{MW}, 160^{\circ} \mathrm{C}, 20-45 \mathrm{~min}$

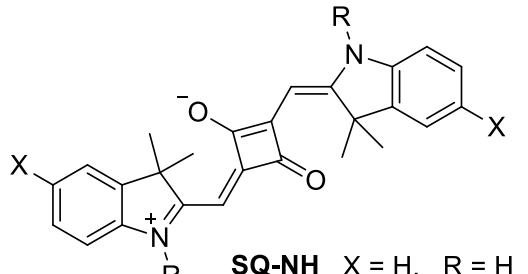

Br-NH $\quad X=B r, R=H$

Br-C2 $\mathrm{X}=\mathrm{Br}, \mathrm{R}=\mathrm{C}_{2} \mathrm{H}_{5}$

Br-C4 $\mathrm{X}=\mathrm{Br}, \mathrm{R}=\mathrm{C}_{4} \mathrm{H}_{9}$

I-NH $\quad X=I, \quad R=H$

I-C2 $X=I, \quad R=\mathrm{C}_{2} \mathrm{H}_{5}$

I-C4 $X=I, \quad R=\mathrm{C}_{4} \mathrm{H}_{9}$

Scheme 3. Synthesis of squaraines. 


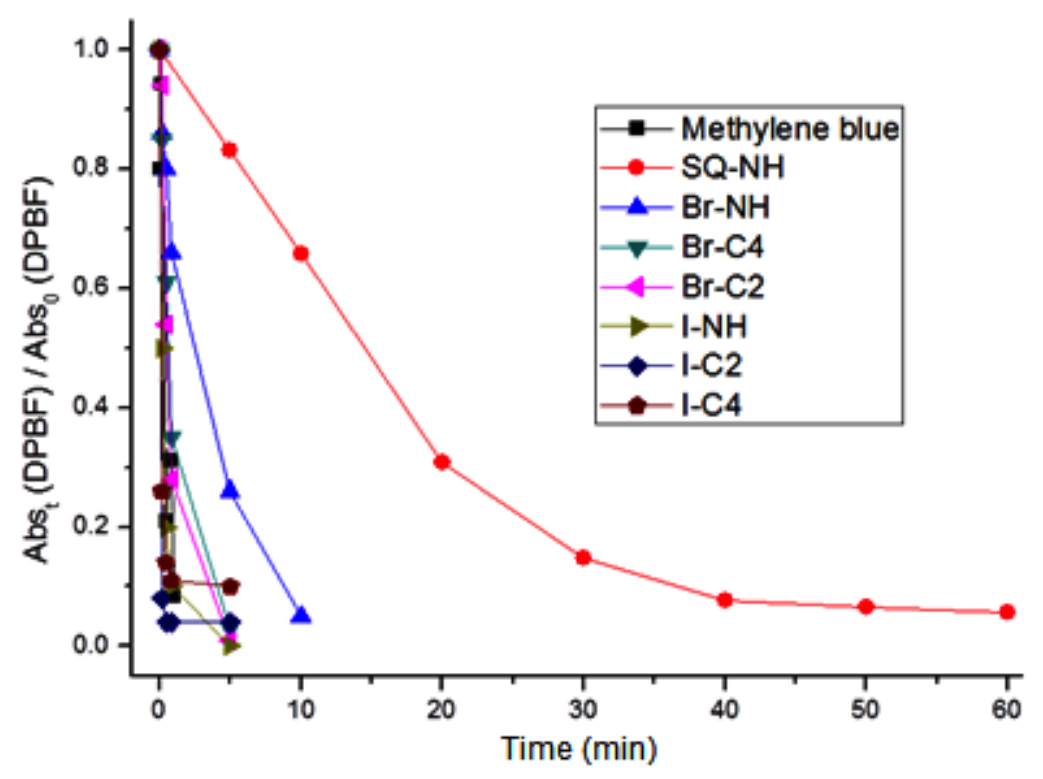

Figure 1. Comparative synthesized squaraine ${ }^{1} \mathrm{O}_{2}$ generation with methylene blue as standard reference. 

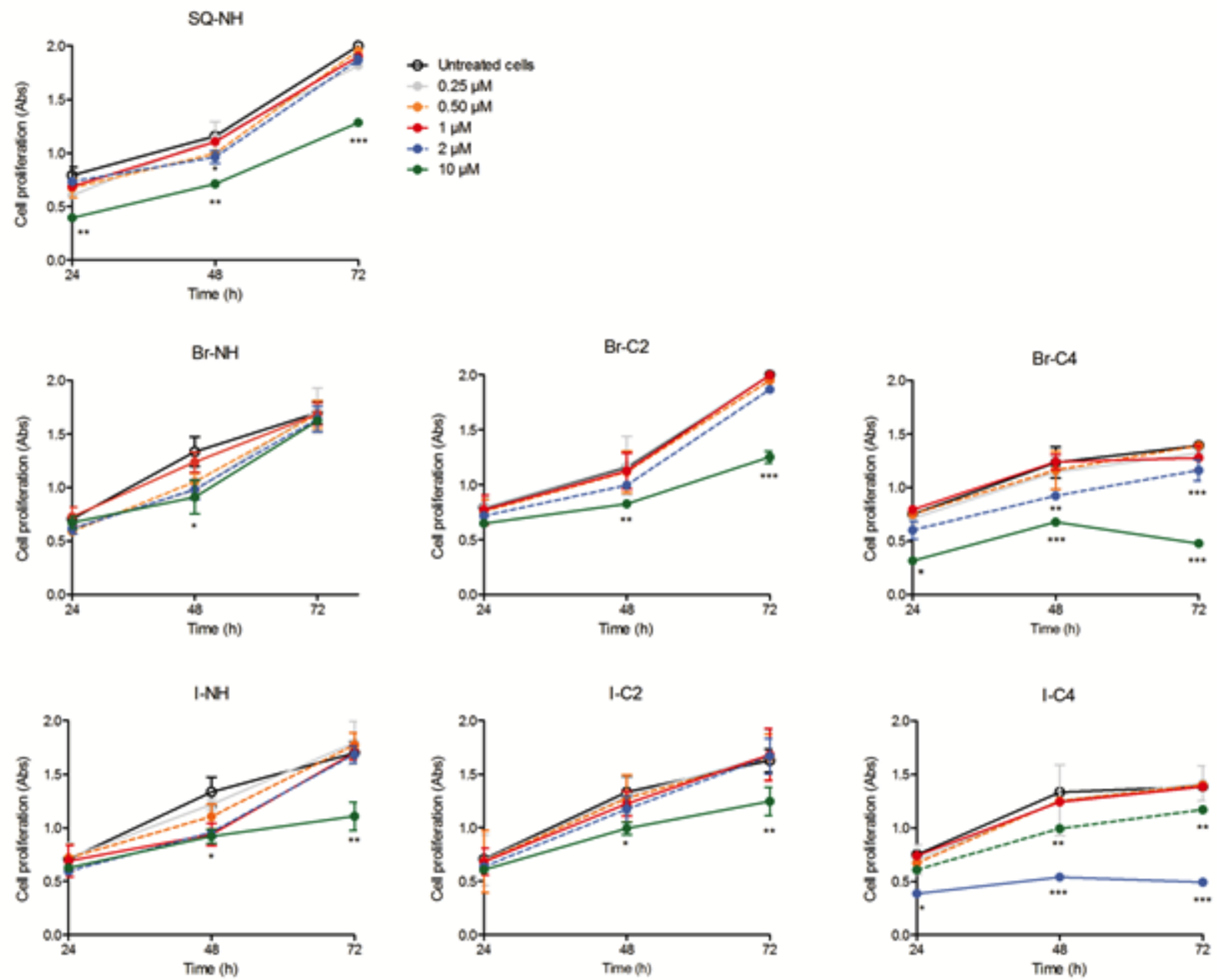

Figure 2. Effects of squaraine dyes on HT-1080 cell proliferation. Cell proliferation, after exposure to increasing concentrations of squaraine dyes $(0.25,0.50,1,2,10 \mu \mathrm{M})$, was evaluated at 24,48 and $72 \mathrm{~h}$ by WST-1 assay. Statistical significance versus untreated cells: ${ }^{*} \mathrm{p}<0.05,{ }^{* *} \mathrm{p}<0.01,{ }^{* * *} \mathrm{p}$ $<0.001$. 


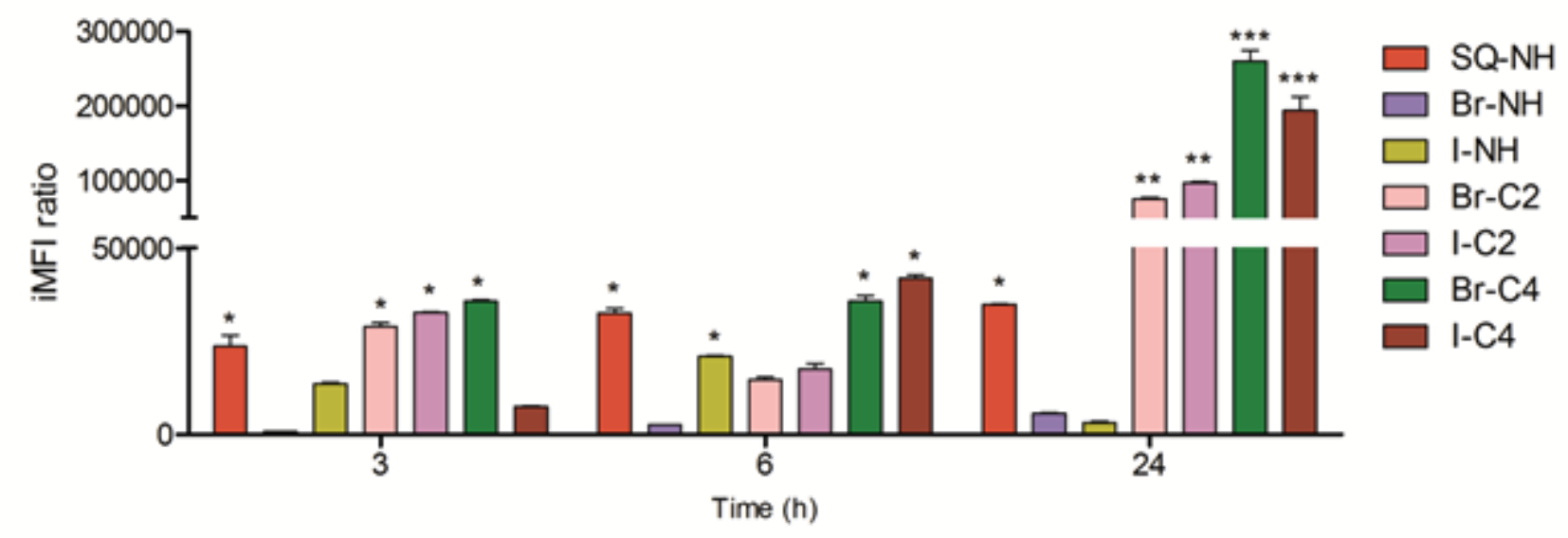

Figure 3. Squaraine cytofluorimetric cellular uptake. HT-1080 cells were incubated with squaraine dyes at the same concentration $(1 \mu \mathrm{M})$ for 3, 6 and $24 \mathrm{~h}$. Fluorescent signal was detected using a flow cytometer at $540 \mathrm{~nm}$ excitation to measure the intracellular squaraine and expressed as the integrated median fluorescence intensity (iMFI) ratio calculated as reported in Materials and Methods. Statistical significance versus untreated cells: ${ }^{*} \mathrm{p}<0.05,{ }^{* *} \mathrm{p}<0.01,{ }^{* * *} \mathrm{p}<0.001$ 

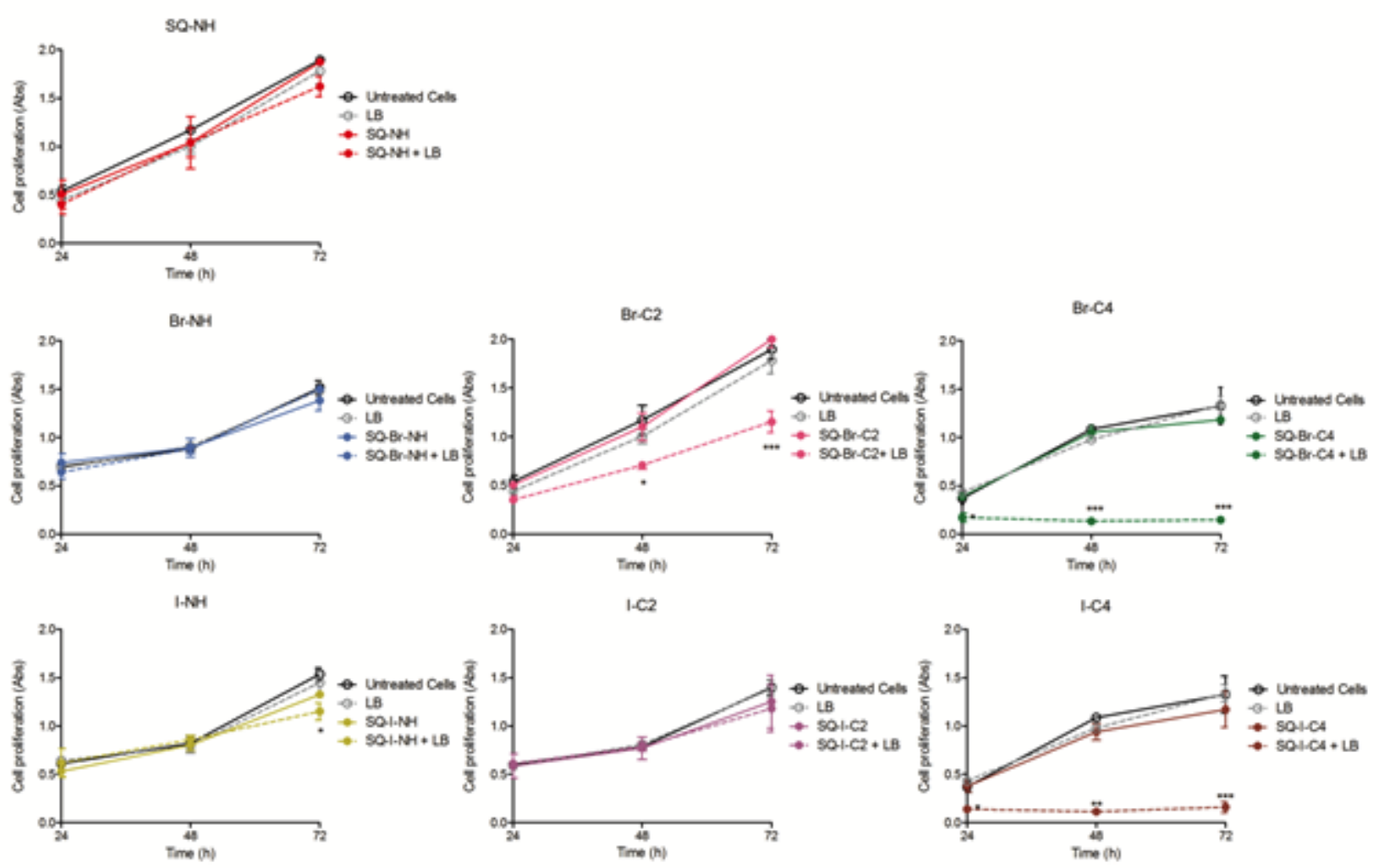

Figure 4. Effect of photodynamic treatment on HT-1080 proliferation as a function of time. Cells were incubated for $24 \mathrm{~h}$ with different squaraine dyes at the same concentration $(1 \mu \mathrm{M})$ and then exposed to PDT with a light beam (LB) at $15 \mathrm{~mW} / \mathrm{cm}^{2}$ for $20 \mathrm{~min}$. Cell proliferation was evaluated after 24, 48 and 72 h by WST-1 assay. Statistically significant difference versus untreated cells: ** $\mathrm{p}<0.01, * * * \mathrm{p}<0.001$ 

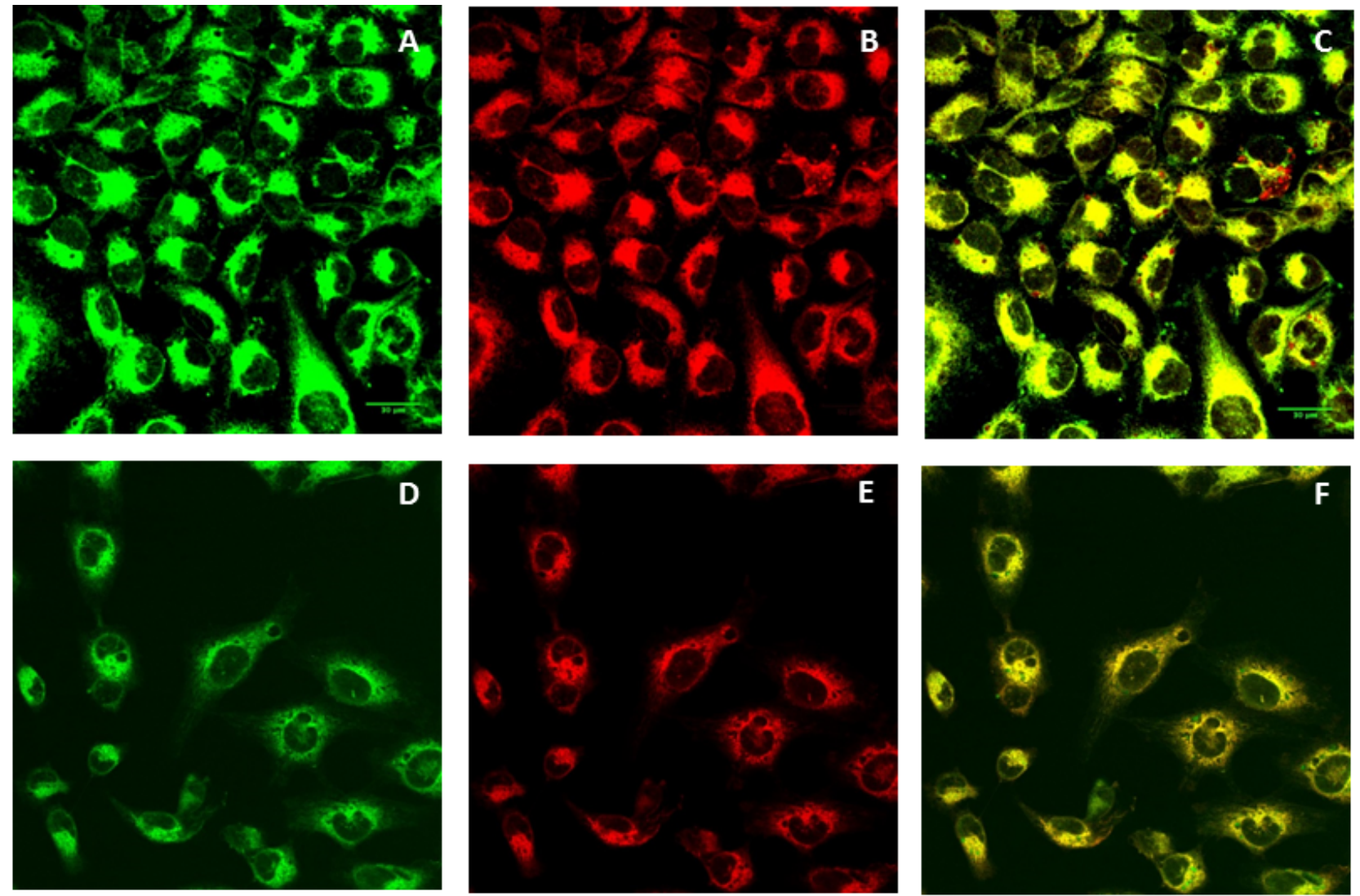

Figure 5. Squaraine dyes colocalize with cell mitochondria. Representative confocal fluorescence images of HT-1080 cells incubated with either Br-C4 or I-C4 (red signal) at the same concentration $(1 \mu \mathrm{M})$ for $24 \mathrm{~h}$ and MitoTracker Green (green signal) $(100 \mathrm{nM})$. A-D, MitoTracker Green; B-E, Br$\mathrm{C} 4$ and I-C4, respectively; C, merged imagine of panels A and B; F, merged imagine of panels D and E. Fluorescent signal was detected by a confocal microscopy with 488 and $568 \mathrm{~nm}$ excitation, at 60x magnification. 


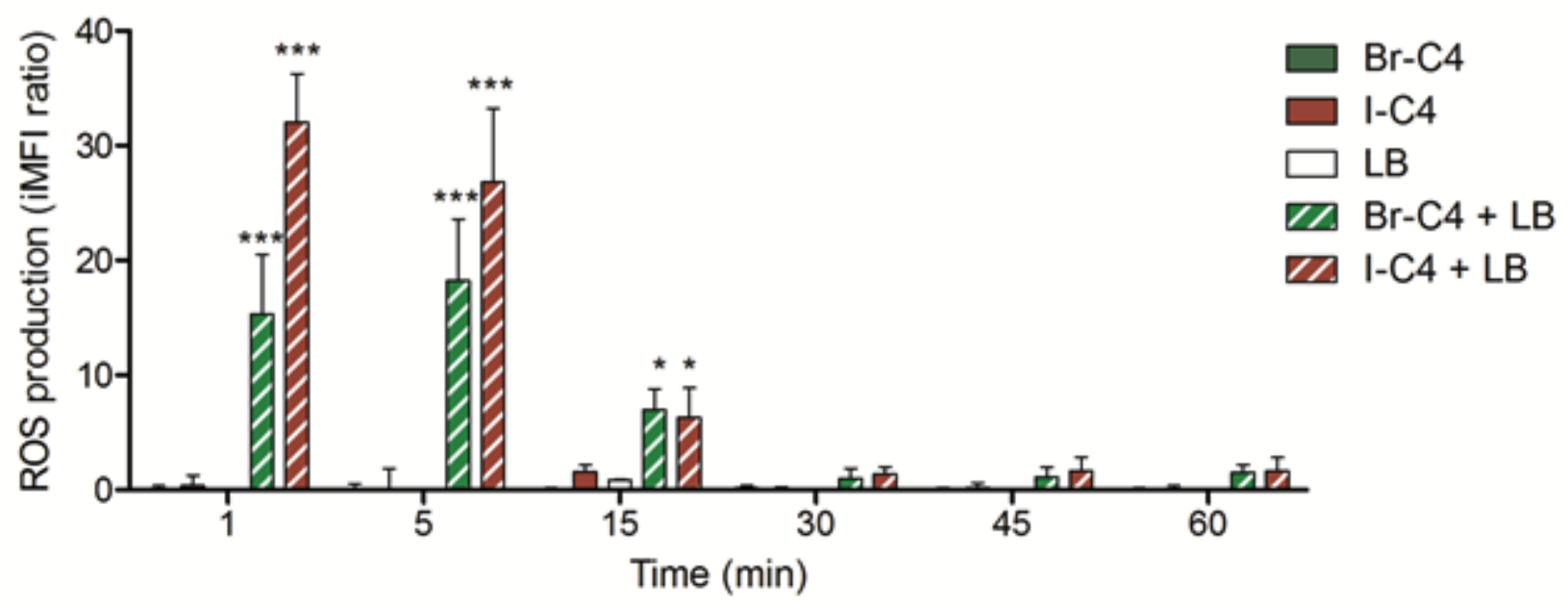

Figure 6. HT-1080 reactive oxygen species (ROS) production after PDT as a function of time. HT1080 cells were exposed to PDT with a light beam (LB) at $15 \mathrm{~mW} / \mathrm{cm}^{2}$ for $20 \mathrm{~min}$, alone or after cell incubation for $24 \mathrm{~h}$ with $\mathrm{Br}-\mathrm{C} 4$ or I-C4 at the same concentration $(1 \mu \mathrm{M})$. ROS levels were determined according to the dichlorofluorescin-diacetate assay by flow cytometry and expressed as the integrated average fluorescence ratio (iMFI) ratio, as described in Materials and Methods. Statistically significant difference versus untreated cells: ${ }^{*} \mathrm{p}<0.05, * * \mathrm{p}<0.01,{ }^{* * *} \mathrm{p}<0.001$. 


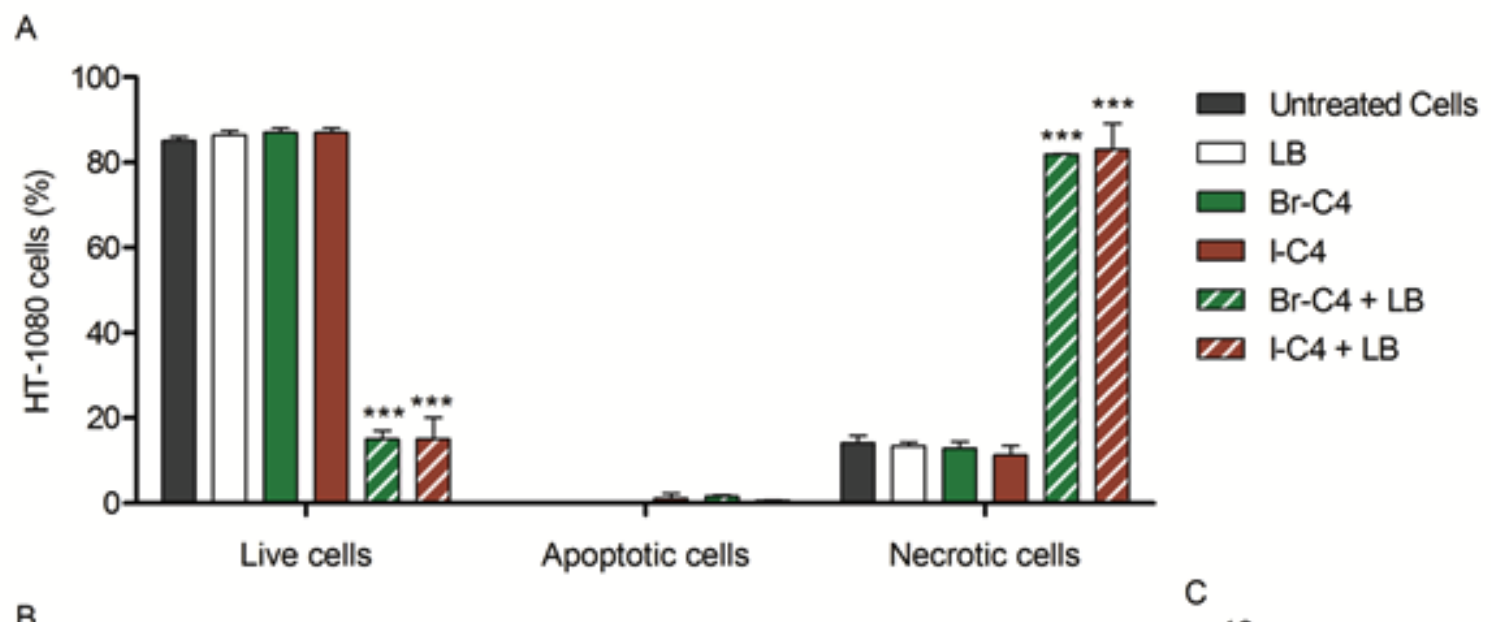

B
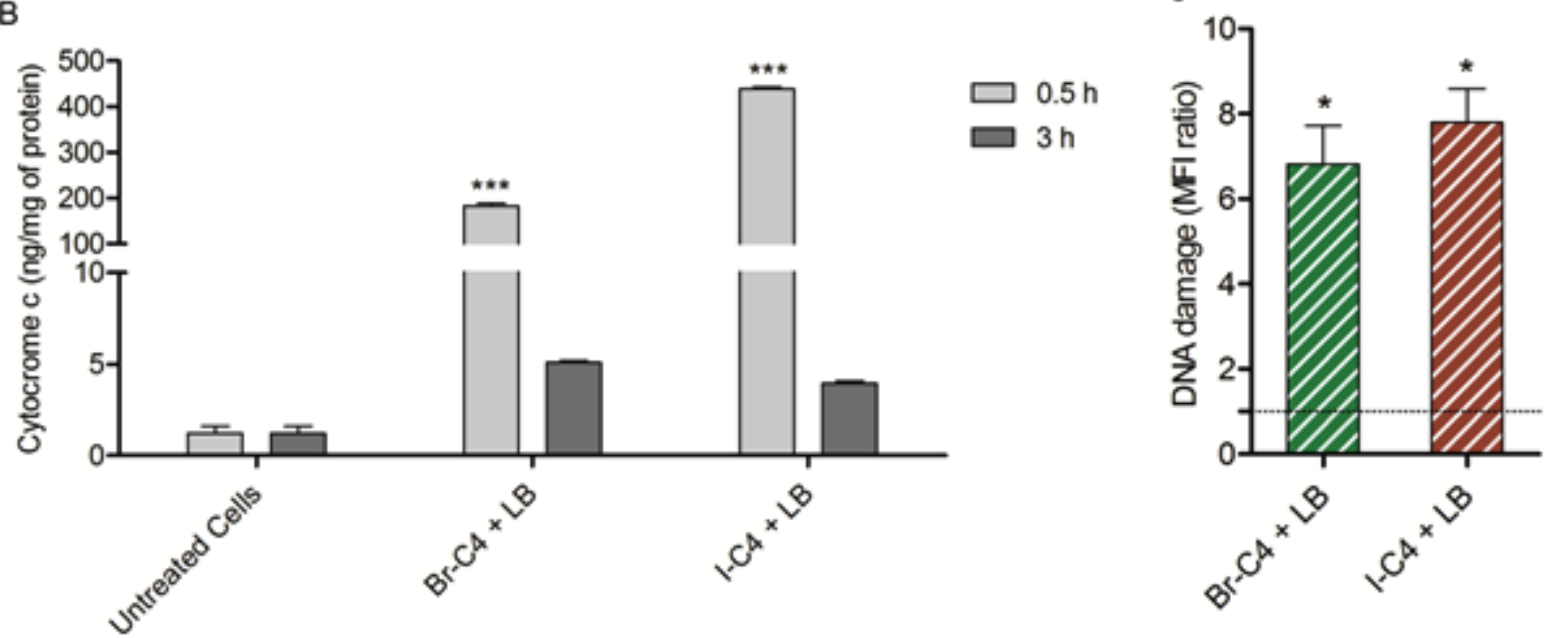

Figure 7. Effects of photodynamic treatment with squaraine dyes on cell death, cytochrome c release and DNA damage. HT-1080 cells were exposed to PDT with a light beam (LB) at 15 $\mathrm{mW} / \mathrm{cm}^{2}$ for $20 \mathrm{~min}$ alone or after cell incubation for $24 \mathrm{~h}$ with $\mathrm{Br}-\mathrm{C} 4$ or I-C4 squaraine dyes at the same concentration $(1 \mu \mathrm{M})$. Panel A: Percentages of apoptotic and necrotic cells were obtained $6 \mathrm{~h}$ after treatment by flow cytometry with Annexin V-Alexa Fluor ${ }^{\circledR} 488$ and Propidium Iodide (PI). Panel B: Cytochrome c was evaluated 0.5 and $3 \mathrm{~h}$ after PDT. Panel C: PDT induced damage in DNA was evaluated 30 min after treatment and the effect was compared to untreated cells, which are stated as 1 and shown by the dotted line.

Statistical significance versus untreated cells: $* \mathrm{p}<0.05, * * * \mathrm{p}<0.001$ 

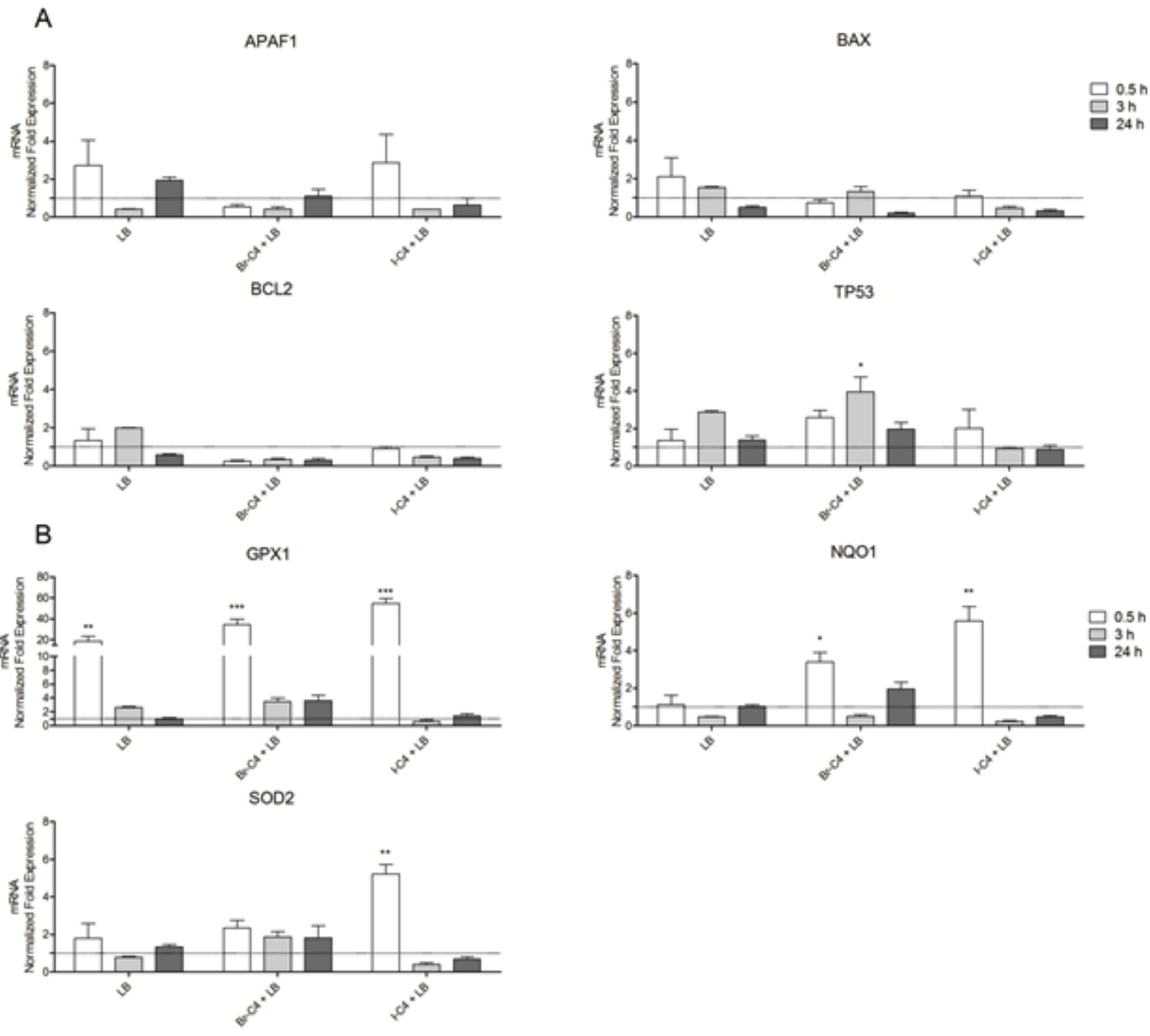

Figure 8. mRNA expression analysis in HT-1080 cells, $0.5,3$ and $24 \mathrm{~h}$ after PDT. Cells were incubated for $24 \mathrm{~h}$ with either Br-C4 or I-C4 at the same concentration $(1 \mu \mathrm{M})$ and then exposed to PDT with a light beam (LB) at $15 \mathrm{~mW} / \mathrm{cm}^{2}$ for $20 \mathrm{~min}$. RRN18S (ribosomal RNA 18S) was used as a reference gene to normalize the data. The photodynamic therapy-induced alterations in mRNA levels were compared with those of the untreated cells which are stated as 1 and shown by the dotted line. Panel A: mRNA expression of genes involved in the apoptotic pathway; Panel B: mRNA expression of genes involved in the oxidative damage pathway. Statistically significant difference versus untreated cells: $* \mathrm{p}<0.05, * * \mathrm{p}<0.01, * * * \mathrm{p}<0.001$. 